\title{
Leadership towards a just economic society
}

\section{J A Lombard \& N J Schoeman'}

(University of Pretoria)

\section{ABSTRACT \\ Leadership towards a just economic society}

This actuality article on leadership argues for the need to move towards a just economic society. The implications of different terms are considered within a conceptual framework. This framework is essential for a better understanding of economic justice in an institutional environment, where economic relationships and economic justice has come to dominate public debate. The relations between public opinion and material wealth are analysed before justice in a mixed economy receives attention. Related conditions are discussed in succession, firstly, individual freedom and the Rule of Law, and secondly, distributive justice. The article then proceeds to discuss challenges for economic leadership in South Africa, indicating trends present in both the theoretical and political leadership current in the rest of the world. Perspective is thereby given on the situation in South African democracy, where the political focus has moved from the issue of justice as freedom, to justice in the distribution of wealth and income.

\section{INTRODUCTION}

"It is you and I sir, who started this process of reconciliation in the country. And we committed ourselves to a peaceful settlement of South Africa's problems ... We agreed that we had to settle our problems as brothers, as children of the Lord, instead of with force and violence ... We have fought our battles, but it is now the time for working, and to build. The leadership in this country must think with their brains, and must suppress the feeling in their blood" (Nelson Mandela to P W Botha during a visit to Botha's home, Die Anker [Prinsloo, 1997: 434]).

In the year 1963,when Martin Luther King (Jr) addressed 250000 people in Washington DC on his dream for the future, Nelson Mandela had to

\footnotetext{
1 N J Schoeman is professor in Economics, Department of Economics, University of Pretoria and J A Lombard is emeritus professor, Department of Economics, University of Pretoria.
} 
make his final statement to the Supreme Court in Pretoria before being sentenced on an indictment of high treason. These were some of his words (Meer 1998: 241):

"At the beginning of June 1961, after long and anxious assessment of the South African situation, I and some colleagues came to the conclusion that as violence in this country was inevitable, it would be wrong and unrealistic for African leaders to continue preaching peace and non-violence at a time when the government met our peaceful demands with force. It was only when all else had failed, when all channels of peaceful protest had been barred to us, that the decision was made to embark on violent forms of political struggle ... The government had left us no other choice. I can only say that I felt morally obliged to do what I did."

After 27 years in jail, and as President of the new democratic Republic of South Africa, Nelson Mandela spoke to his erstwhile political adversary in the words quoted in the opening paragraph of this essay. Thus in drawing the lines of the battle for justice in 1961 and stepping across them in the sight of victory in 1991, Nelson Mandela gave history one of the greatest demonstrations of leadership in bridging the gap between violently opposing factions to set them on the way to a more just society.

\section{LEADERSHIP AND JUSTICE - A CONCEPTUAL FRAME- WORK}

There can be no doubt about the importance of leadership in the history of societies and of the importance of the ideas that motivated these actions. Thus, when Moses led his people out of Egypt through the desert towards their promised land more than three millennia ago, his wise old father in law, Jethro, came to him in the desert and gave him the good advice "to select capable men from all the people, men who fear God, trustworthy men who hate dishonest gain - and appoint them as officials over thousands, hundreds, fifties and tens" (Exod 18:21). The subject of leadership and its inspiration also greatly interested the Greek philosophers 700 years later. This time it was not "the fear of God" that was considered to be the guiding light but "reason". Plato, in particular, in his Republic laid the foundations for applying reason and critical analysis to the solution of political and social issues. Thus his insistence that in the selection and education of the "guardians" of the state the basic inquiry should be about the meaning and origins of justice and injustice (Ebenstein, 1969:2). For the Greeks, the road to justice was to be found in the right word, which had to be formulated; for the Hebrews 
it was to be found in the right relationships, which had to be demonstrated.

An initial assumption in this essay is that an objective, absolutely valid, all embracing concept of justice has, like absolute perfection, remained beyond the ability of mankind to formulate. For while a totally just society must surely be the ideal, justice in such an absolute and all embracing sense seems to be only fully known to God, and could only be understood and practiced by us through perfect obedience to His will. It is also true that the fall of man into the sin of disobedience has robbed us of this understanding. At best we can try to deal effectively with specific injustices as we find them in particular situations.

Secondly, because thought in this field is typically controversial, people need leaders for guidance. As the anthropologist, Ralph Linton (Barcley 1971:95) stated: "No society as a whole ever produced an idea...." There is always some one individual or a very small group of individuals who are firsts to accept or reject the new thing, and their reaction is followed by a gradual transmission of their attitudes to the rest of society. As William Barclay remarked, "whatever you say, someone will think differently!" Controversy is not an issue in a dictatorship, but it is an issue in a true democracy. That is why a eading economic philosopher like John Stuart Mill (Robbins 1963:31) more than a century ago, maintained that freedom "has no application to any state of things anterior to the time when mankind have become capable of being improved by free and equal discussion", or as Robbins (1963:31) added, a civilised society is one in which the leaders of public opinion are able to persuade and be persuaded. It is indeed this quality of leadership in thought, if not also in action, that is decisive in determining the durable evolution of the order of society.

To this end, good leadership should define the problem, not merely in terms of its symptoms but also in terms of its causes. Conciliation in terms of the symptoms only will not last, for if the causes of the problem remain, it will recur - a classic case being the shortsighted Peace Accord of 1919 in Europe, which simply laid a foundation for the next World War twenty years later. But more than that, leadership should also approach the conciliation with the objective of creating a new future rather than simply patching up the past. This requires not merely a strategist, but a personality whose nature is at once visionary for his own people, as well as for all the people who will be meaningfully affected by the new order. Moreover, good leadership includes the responsibility to choose the best reform team and to assist them in understanding and executing their particular responsibilities (turning "disciples" into "apostles"!). 
Thirdly, in economic affairs outside the political arena, the art of leadership is not usually about conducting dramatic negotiations with contemporary adversaries. It is more often about "negotiating with the future"! To "step outside the boundaries of routine", as Schumpeter (1947:132) said; to take risks acting on one's own judgement and expectations about how the future will deal with one's current decisions. This also requires the "effort of will" as well as the courage to endure "the reaction of the social environment against one who wishes to do something new". These are, of course, the qualities of the entrepreneur, the essential leader in the process of economic growth.

Fourthly, the meaning of "society" also needs closer description, especially in the politics of economic justice. Do we have in mind the whole human race as our society, or do we confine our standards to the limits of democracy in politically constituted national states? Had we lived in Europe during the middle ages, the span of our emotions would normally have been defined by the universal society of the Catholic church. By the middle of the $18^{\text {th }}$ century this universalism was breaking up in favour of the statism of small principalities where very little if any emotional feelings for society in any sense remained. According to Kohn (1945:198), it was only with the emergence of nationalism at the end of the $18^{\text {th }}$ century that the emotional bonds of "society", the intimacy of union which religion had provided, returned. In this intimacy a major part was played by language, "the most wonderful and useful instrument for the maintenance of the society for which man was born". This point should not be lost sight of. Language is the instrument of civilised debate, of the processes of persuasion. As the bearer of the culture of a people, it subconsciously harbours values which are bound to be important in people's conceptions of the morality of particular situations.

We are now, at the turn of the $21^{\text {st }}$ century, experiencing the integration of individual states into larger regional - in some respects global - political entities. The question is to what extent our quest for justice in society will remain confined to the bounds of the national state and its society, or will South Africans, for example, extend their emotions, actions and commitments about economic justice to encompass all people in the Southern African Development Community, or the Commonwealth of Nations, or the New African Union, or even further afield? Is there a geographic or other cut off point in the principles of equal human rights in general which might grant the idea of "equal but separate" (or the other way around) some justification? Reactions to this question in terms of economic justice depend heavily on the extent to which the economic relationships among individuals are regulated by particular governments - a matter that will be addressed below. 


\section{ECONOMIC JUSTICE IN AN INSTITUTIONAL ENVIRON- MENT}

\subsection{Introduction}

Our two-fold proposition that: (1) since the identification of absolute justice in reality eludes the imperfect wisdom of mankind, we are confined to deal with the occurrence of specific injustices as and when they arise in the minds of people; and that (2) this required leadership in both thought and action, is nowhere more relevant than in the economic relationships among people in the society. There are two reasons for this:

First, there is the fact that economic relationships are basically concerned with the problem of the scarcity of resources in relation to the demand for them to satisfy human need and desires. Scarcity is, of course, the essence of the curse of our disobedience to the will of Providence. "Cursed is the ground because of you; through painful toil you will eat of it all the days of your life" (Gen 4:17). Furthermore, the desire of the human race for goods and services that require scarce resources, is limitless.

The second reason why the matter of economic justice has come to dominate public debate is, indeed, the very rapid growth in material wealth since the cultural renaissance and religious reformation in Europe in the sixteenth century, and especially since the industrial revolution of the nineteenth century throughout the western world, These tremendous changes in people's opportunities for material well-being inevitably infected their ideas about how to spend their time and their thoughts. Public opinion and politics became dominated by the consideration of material wealth, while the matter of justice in economic relationships came to take the centre stage.

The main vessel for this cultural revolution towards materialism was the so-called market mechanism - that particular organisation of economic behaviour that spontaneously arises from the logic of specialisation in what one does best, and trading for what one wants most at the terms of exchange, or prices, determined (objectively!) in the market by supply and demand. This is usually referred to as "the price mechanism". Furthermore, money, as the generally acceptable medium of exchange, extended into credit arrangements to allow for payments over time and as a store of capital. As this process of specialisation in production during the industrial era required, and indeed created, a vast accumulation of capital to combine with the available labour and land, and since this capital was privately owned, the market economy and its price mechanism also became described in political debates as capitalism.

But the market mechanism was never completely free of government intervention. The market systems in society always needed 
the complement of government at least to establish and maintain the order within which the market operates, and to protect the order from outside interference. But most governments also participate or interfere in the market process beyond these "order functions" in the production of good and services. These actions may be labelled their "welfare functions". This, then, is the so-called "mixed economy", and it is over the wisdom and fairness of the "mix" that intellectual and political battles are fought.

Justice in the mixed economy usually refers to two conditions. The first to be discussed is individual freedom and the Rule of Law. This aspect will be discussed first, mainly because it is a necessary condition for both the existence of private enterprise and the market mechanism in the mixed economy. The second condition is commonly referred to as distributive justice, or the fair distribution of income and wealth (assets) among the members of society. As will be discussed below, the imposition of norms of distributive justice on the performance of the market tends to qualify the degree of individual freedom, and vice-versa. Although these matters are thus in many respects interrelated, they will for the sake of clarity be discussed in succession.

\subsection{Individual freedom and the Rule of Law}

Individual freedom in a mixed economy refers primarily to people's freedom of property, of contract, and movement (in which the "freedom of opportunity" is tacitly implied). These are what one might call "passive" freedoms from the point of view that they do not require any action from the members of society except mutual respect. In recent decades more "active", economically significant concepts of individual freedom, which require action by society, have been put forward The most prominent of these is the "freedom from want" as proposed by Franklin Roosevelt during his "New Deal" campaign in the United States of America. A South African variant, included in Chapter Two (the Bill of Rights) of the country's new constitution, is qualified rights to housing (Art 26) and health (Art 27). These conditions are, however, closer in nature to those of distributive justice than to the "passive" freedoms discussed here.

There can obviously be no such thing as absolute individual economic freedom in a free society; for absolute freedom for one member would necessarily imply the obstruction of the freedom of everyone else. A free society, accordingly, requires a legal ordering or limiting of subjective personal claims as objectively as possible. But opinions differ about how these limits should objectively be defined in law, to be regarded as just. In fact, although the idea of such personal freedom is as old as civilization itself, the legal dispensations of degrees 
of freedom for particular classes of people in society, have differed considerably over time and between states. In terms of modern perceptions of justice, the extent to which these discriminations in the legal status of classes of people in the same society (like slaves in Roman times) were at the time regarded as quite normal, is indeed remarkable!

But as much as individual freedom - or liberty - in the mixed economy requires objectively formulated laws, passed and administered by governments, their value for the members of society depends upon the extent to which they can be relied upon to last. Laws made by governments or other authorities can be unmade by them or their successors. Also, changed circumstances often require changes in laws. In general it could be said that an act is unfair and creates an unjust economic society if it deprives any individuals of their basic economic rights to adequate shelter, education and health. However, what then is the limit to the state's responsibility regarding the level of education or the provision of shelter? It is in this area that individual judgment complicates the task of policymakers, resulting in severe criticism from those affected by these policies. Thus, the problem is that in the pursuit of fairness, it is possible to adopt measures that result in economic inefficiency through resource misallocation, and in the end injure precisely those persons whose interests require some protection from the state. A sense of freedom implies a sense of certainty. Effective justice in a community thus needs the subordination of ordinary laws of governments of the day to a higher rule of society contained in its common law or its constitution as the articulation of its basic traditions and consensus about individual freedom. This is known as the Rule of Law. In Dutch jurisprudence a very instructive differentiation is made between "reg" as the common law above the statutory "wet" made by the present-day government. According to Hayek (1955:34) three classic requirements of any legal system to be considered as constituting the Rule of Law are, above all others, that the laws must be "general, equal and certain".

In the Republic of South Africa such a Rule of Law for the economic freedom of the individual has been established in Chapter Two (Bill of Rights) of its constitution enacted in 1996. It reflects the spirit of the common laws of the early Dutch and English settlers in South Africa during the $18^{\text {th }}$ and $19^{\text {th }}$ centuries, but with the fundamental difference that only since 1996 has this rule been applicable to all South Africans irrespective of race. The splendid way in which this constitution developed during the early 1990s, from the conciliation of the two political forces of the $20^{\text {th }}$ century, the Afrikaner National Party (NP) and the African National Congress (ANC) reflects the quality of leadership in South Africa at that time, evolving towards a more just society. The thoughts and actions of Nelson Mandela through the history 
of the ANC's post world war II "struggle", and his eventual spirit of conciliation, are vividly recorded in his Long Walk to Freedom. However, the important role of church and business leaders in persuading the National Party to abandon the idea of Apartheid and bringing the two sides together amidst threatening break-downs, should not be underestimated.

The maintenance of this Rule of Law in South Africa in the $21^{\text {st }}$ century is, however, not a mere matter of impersonal management by the present-day government administration. It requires consistent leadership, not only on the political level, but especially on the civilian level, that is in the various non-governmental institutions representing the material interests of the diverse factions of the new society. There is bound to be a call for changes in the distribution of land in South Africa, which will require new legislation, but the agreed Rule of Law should be regarded throughout. There is something to be said for the view of the contractarian school of thought on justice, that major changes in the stipulations of the social accord would be unjust, once a social accord has been reached to which society has contracted, developed its interests and fixed its hopes in. Even in the case where laws pertaining to private rights to water, mineral deposits, competition etc, might need revision, frequent significant changes, without broad consent could cause great uncertainty in the market economy regarding the direction of political intervention. If changes in the basic rules of the game prove to be necessary, consensus in public opinion will require strong leadership in civil society to create sufficient understanding among those negatively affected.

\subsection{Distributive justice}

The second element of economic justice - the fair distribution of income and wealth among the members of society - has raised and will raise even more challenges to leadership in society than the protection of individual freedom. This is because, even though the idea of the freedom of property and contract may be accepted as a necessary condition for the existence of a market economy, that does not mean that everyone necessarily agrees that the outcome of these operations are fair. There is, moreover, much less ideological controversy about the meaning of freedom than about distributive justice.

It therefore becomes necessary to briefly note the fundamental differences between three main schools of "secular" thought on justice in economic relationships. They will be referred to as the "economic libertarians", the "economic collectivists" (including the "socialists") and the "structuralists".

Broadly speaking, the differences about distributive justice between the first two ideologies relate to the important question of 
whether or not justice is associated with "equity" or with "equality" in the distribution of income. Equality is taken by some to mean that everyone should receive as much pleasure as everyone else from the economy, and by others that everyone should be equal in terms of objective indices like money wages. Equity, on the other hand, means equating people's benefits from the economy with their worth and responsibility in the system, or equating rewards with "value added". (But equity does forbid discrimination in the absence of differences in this respect). This may raise questions about what is to be regarded as value (when the objectivity or fairness of market prices for goods and services are questioned), but there is at least the suggestion that a particular distribution, which is regarded as equitable, need not also be equal to be regarded as just.

Economic liberatarianism insists on limiting the role of government in economic affairs to a minimum beyond the "order functions" of maintaining domestic law and order and protecting the state against outside aggression, while providing certain public services that are clearly necessary for the production and the efficient operation of a market orientated society. As far as the outcome of market operations are concerned, the true libertarian would maintain that to the extent that they result spontaneously from the voluntary actions of the members of society, they are neutral towards the ethics of the given competing ends they serve. Therefore they could not, a priori, be said to be unjust.

The important point for libertarians is that the price mechanism of these spontaneous free market forces presents the most efficient arrangement for regulating the three welfare functions of the economy. These are the allocation of scarce resources, or factors of production among competing applications; the distribution of the produced income (or output) among the competing owners of the factors of production including the owners of labour; and the creation of new output or economic growth in society as a whole. The neo-classical economic theory held by the libertarian school, explains that market prices regulate these functions in three ways: first, prices are signals to market participants of the most advantageous resource allocation; second, participants respond rationally to these signals; third they act freely in their rational responses to these signals (Arndt 1988: 221).

The kind of welfare functions of government, which are accepted as necessary by libertarians, arise logically from the recognition of particular market inadequacies and market failures. Market inadequacies refer to inherently collective goods such as public health provision. It is not possible to produce and sell public health provision on the market in such a way that all users pay a price in relation to what they have in fact 
enjoyed. Because no one can be excluded from such benefits once available, too many users will prefer to be "free riders". Accordingly they have to be coerced to contribute to the cost of the service. Market failures arise from (Pigovian) "externalities" because of important deviations of private costs and benefits from the social costs and benefits of the private activities. Examples would be the underestimation by private producers of the costs to other members of society of their undertakings such as industrial pollution or the social advantages of a new railway line.

While neoclassical economics regards such market inadequacies in general as just grounds for government intervention, the pure libertarian will still have serious reservations about the way in which governments try to remedy the inadequacies and how the burden of the remedies are distributed among the beneficiaries. The focus usually falls on the justice of fiscal policies in distributing the financial burdens involved among the members of society. Libertarians are very sceptical about welfare functions by government agencies whose actions they contend, suppress market efficiency, introduce bureaucratic inefficiencies, and aim at patterns of income distribution that have no undeniable claim to be more just than the outcomes of the free market. The bureaucracy is held to be neither particularly efficient nor effective in the functions of allocation, distribution, and growth.

Both opposing schools of thought mentioned above regard the mere recognition of individual freedom in society as quite insufficient, and sometimes even questionable, in securing a just distribution of economic welfare in society (which is usually taken to mean the greatest good for the greatest number of people).

On the extreme left, the Marxist ideology of communism regards the outcome of the exercise of freedom of property and contract (described as capitalism) as not only totally unjust, but also doomed to failure as a result of the "inevitable revolution" of the proletariat against the exploitation of the working class by the owners of capital. Because Karl Marx himself had little if anything to say about how society would be managed after the revolution, it was left to the administrative talents of Lenin, to introduce a system of totalitarian planning and bureaucratic control over the processes of allocation and distribution in Soviet Russia after the 1917 revolution. However, the collapse of this totalitarian state in 1991 demonstrated that justice, however defined, cannot be served by the imposition of a system of total control that simply cannot work.

The various shades of non-totalitarian collectivists advocating much milder forms of government control over (rather than substitution of) market forces, continue to hold that the outcome of the operation of market forces, and the price mechanism in particular, are in practice 
ethically or morally unacceptable. The market must, therefore, be guided politically towards preconceived social goals in general, and "distributive justice" in particular. In contrast to libertarian propositions of particular market failures that required particular remedies, the collectivist scheme of things conceived an overall vision for the economic life of society that could be properly articulated in a prescriptive programme for the mixed economy to deliver. This would turn the mixed economy into a well-ordered social welfare state.

Efforts of economic theorists like the Italian Vilfredo Pareto and members of the Cambridge School, proved to be flawed in designing a method of positive economic logic that would allow a fully fledged schedule of ends, or "social welfare function", to be deduced logically from the summation of the individual preferences of the members of society (Graaff 1971). Economic policy prescriptions cannot be derived purely from the formal logic of positive economic theory. All policy prescription must necessarily involve normative judgements belonging to the domain of politics in general (of which economic policy is an integral part rather than a separate category).

This change from positive to normative arguments gave rise to teleological analyses of both the system of market forces as well as the array of political ends in quantitative economic terms (Tinbergen 1956). Such models claimed to make it possible for government policy to comprehensively guide the mixed economy "from above", that is by means of fiscal, monetary, industrial, agricultural and other policy "instruments", towards preconceived goals. Such approaches contrast diametrically with the libertarian logic which suggests policy targets "from below". (Note that both approaches accept the explanation of neoclassical theory of how the market mechanism works. They differ mainly on how the agenda of government should be inspired: by the narrowly defined "market failures" or by the broadly arrayed wishes of the democracy).

The idea of social welfare states with a welfare function or a "five year plan" took hold of political imagination in Britain and many countries in western Europe after World War II. Thus the welfare state idea, adopted mainly by labour-orientated governments, promised not only full employment, safety nets and higher standards of living for the poorer sections of the community, but also more equality in incomes throughout society. In practice, however, the outcomes of these radical social welfare programmes turned out rather differently: rates of growth declined and taxes and prices rose, while the coefficients of income distribution did not change a great deal. Socialist parties usually found that once in power, the complexity of practical circumstances forced them towards much less radical ideas in the management of the mix 
between public and private responsibility for the welfare functions in their societies. It seems inevitable over the coming decades that economic growth, which could raise the income levels of the poor, also would increase the gap between the rich and the poor. The left-of-centre parties now in power in the west speak the language of equality of opportunity rather than equality of outcome. For the present at least the egalitarianism that animated old-style socialism or social democracy, appears to be dead as a political force in these countries.

Leading theorists in the "structuralist" school, who have considerable influence on much of the political leadership in the emerging market economies in Africa and the rest of the third world, accept neither the justice nor the efficiency of the market mechanism as claimed by neoclassical economic theory. The emphasis in their reservations is on questioning the institutional assumptions of neoclassical theory rather than its purely formal or mathematical logic. The cultural anatomy of the third world simply differs so substantially from neoclassical assumptions about people's responses to price signals (while these signals are, in any case, quite misleading due to the absence of proper communication and the presence of other transaction costs) that no reliance can be placed on the idea of free market forces to create economic growth with justice in the developing world. According to this school, the emphasis should be on correcting the institutional environment to ensure a decline in extreme inequalities of income and wealth and opportunities. However, there seems to be much less agreement on what constitutes a fair distribution of income. The problem with equity is that it is inextricably intertwined with social values. In its publication Economic Issues No 16 (1998), the International Monetary Fund states that some societies view equity as a worthy goal in itself, because of its moral implications and its intimate link with fairness and social justice. Policies that promote equity can help, directly and indirectly, to reduce poverty. When incomes are more evenly distributed, fewer individuals fall below the poverty line.

\section{CHALLENGES FOR ECONOMIC LEADERSHIP IN SOUTH AFRICA}

These trends, in both the theoretical and political leadership in the rest of the world, give some perspective on the situation in the new South African democracy, where the political focus has now moved from the issue of justice as freedom, to justice in the distribution of wealth and income in the country. The existence of very large inequalities in the country is undeniable, and evidence is readily available (see for example Coetzee 1991). That this huge inequality is also inequitable by any standard, and thus surely unjust, is a conclusion easily arrived at in light 
of the history of restrictions placed on the economic freedom of nonwhites since the beginning of the European settlements, but more arduously under the formal system of Apartheid.

Since it was also clear that the removal of Apartheid would not automatically be followed by spontaneous narrowing of (non-racial) income inequalities to levels that could justly be regarded as normal or equitable, the need for the Reconstruction and Development Programme (RDP), introduced by the new administration immediately afterwards, was obvious. The strong and active support of the aims of the R D P by South African private enterprise (mainly through the Consultative Business Movement and its successor, the National Business Initiative with its Business Trust) could be seen as the continued involvement of leaders in this sector, with the process of sociopolitical transformation toward greater economic justice in South Africa.

On suggestion of its president, Professor Themba Sono (Free Market Foundation 1999), the libertarian Free Market Foundation has recently published Five Steps to Real Transformation. The essence of the five steps are: (1) heal the wounds "physically and psychologically" by empowering the deprived people to seek and exploit their own opportunities; (2) transfer and upgrade title to land; (3) create Economic Development Areas (EDAs); (4) sell state property to pay government debt; and (5) target welfare spending so that it benefits only the really needy as directly as possible. These steps reflect the libertarian faith in the ability of the individual, once equitably empowered, to exploit his particular talents to the full.

The second fundamentally important reform has taken place in the "anatomy" of labour relations. The hub of the new institutional framework is, of course, the National Economic and Development Council (NEDLAC) in which organised labour confers with organised business and government. The most novel aspect of NEDLAC in the political economy of the new South Africa is that its functions are not confined to discussions or negotiations about labour legislation or wage trends, but covers a whole range of economic matters far beyond the labour market proper, including fiscal, trade and monetary policies. This is broadly in line with the current European philosophy of industrial democracy according to which the workers have much more participation in the management and leadership of the economy than mere wage negotiations. Having been elevated to the strongest trade union coalition in the country, COSATU exerts powerful influence on macroeconomic leadership in the economy, in spite of its fundamental differences with current ANC priority of conservative fiscal and monetary policy aimed at regaining macroeconomic stability in the country. 
Leadership battles in and around this NEDLAC forum are bound to profoundly affect the character of distributive justice in South Africa. The ANC has, like the left wing governments of all prominent international trading countries, moved to the centre position in a social market economy, while COSATU continues to hold unadulterated socialist views. This leaves the leadership of the third leg of the triangle, organised business, with a very delicate responsibility to get the political economy on the road to equitable growth. Unfortunately, business also seems to suffer from a more mild split in ideological approach between Business South Africa (the voice of the "old school") and FABCOS (which is said to be strongly committed to radical Black Empowerment).

Allied to these institutional innovations for economic reconstruction in terms of the RDP, are the processes of affirmative action and Black Empowerment. The demands of this policy on the business sector could be understood to be motivated by the aim to remove the economic injustices that were imposed by the system of Apartheid. In fact, leadership in private enterprise seems to support these demands to an extent (as exemplified by the early initiative of the Afrikaner insurance giant, Sanlam, to transfer the controlling equity in its very large subsidiary, Metropolitan Life Insurance, to previously disadvantaged interests). The indefinite continuation of this political pressure for affirmative action would, however, lead to "reverse apartheid" in the character of the South African economy, that would be equally unjust to young South Africans who enjoy no economic favours from the past. It is in fact a pity that the idea of affirmative action was not articulated explicitly in the new constitution with a "sunset clause" dating the termination of the practice!

At the time of writing, a Black Economic Empowerment Commission (BEEcom) appointed by another body (the Black Business Group) submitted an extremely wide-ranging report and detailed recommendations to the President, Mr Mbeki. After thorough exploration of the South African economy, the study's basic objectives seem to sympathise with the idea of a mixed economy with a strong private business sector, provided this is clearly characterised by the participation of a thriving Black bourgeoisie. Libertarian reaction to the broad objective of these ideas should not be altogether negative, particularly as it seems to subscribe to the principle of a limited time span for the execution of its programmes. On the other hand, the various methods proposed may raise serious reservations. They appear to introduce such a plethora of new forms and procedures of state intervention, that they are almost bound to frustrate their own objectives by paralysing the present processes of free enterprise upon which, however racially unbalanced, the political economy still must depend for survival during the transformation. 
Beyond these "secular" schools of thought about the acceptability of the market driven process of income distribution, there are, of course, many religions that deal specifically with the responsibilities of the "haves" to share with the "have nots" in society. A trustworthy critical appraisal of the particulars of their respective directives is indeed beyond the intellectual discipline of economics per se. However, in so far as persons and groups can be inspired by their faith to take care of the needs of their "neighbours" in society, there is nothing in the theories of market economics that regards such missions as counter productive or ineffective. Quite the contrary is true: perhaps the basic solution to the problems of political economy lies in these extra-economic sources of inspiration for our personal behaviour in the market place! (See Professor R H Tawney's conclusions in his seminal work on religion and the rise of capitalism, Tawney, Chapter V).

\section{REMAINING DUALISM IN THE NEW SOUTH AFRICAN DEMOCRACY}

The matter of distributive justice in the new South African democracy, beyond the sins of Apartheid, in the form of the likely persistence of the historic dualism in its entire socio-economic structure, remains to be considered. This dualism is characterised by a highly developed industrial core, closely linked to the industrial first world, surrounded by an economically undeveloped periphery, which at best may be defined as "informal", but which also contains a large number of people still confined to subsistence methods of existence. Economically the (first world) core which is steadily changing from "white" to "grey" is wealthy, while the (third world) periphery is poor. Democratically, hwever, the core is a minority while the periphery is a majority.

The scenario is further complicated by the advent of globalisation in the post industrial world. Leaders of private enterprise in that world argue that the integration of so called "emerging markets" (such as the South African core economy) is not only practically inevitable, but also beneficial to these emerging markets. On the other hand, it has been argued that globalisation, through which the labour, product and capital markets of economies in the world have been integrated, may be blamed for growing income inequality and injustice in emerging economies. Reasons given include the fact that exposure to international competition may impact on the bargaining power of institutions (for example trade unions) and thereby affect income distribution. It is also argued that a policy tool such as monetary policy, has been rendered ineffective, due to the volatility in the flow of capital. Also, fiscal policy may prove to be less effective in terms of particular domestic goals. Tax competition between countries has resulted in low corporate taxes as well as income 
taxes, while indirect taxes such as import tariffs and customs and excise taxes, have been largely phased out. This implies that the incidence of taxes to finance safety nets for those who are dependent on transfers from the government, has been shifted to the workers themselves.

A downside to the process of globalising the South African core economy with the concomitant technology-based demands on entrepreneurial leadership, as well as managerial and administrative skills, is its likely effect of separating the core even further from its African periphery. The production function of the core has been losing its labour absorption capacity for several decades now, and will continue to do so. Moreover, the shrinking demand for intermediate inputs of materials available in the periphery, and the smaller use of space (land) in the present post industrial age, seem to reduce the backward linkages between the core and the periphery (the "trickle down effects") even more!

In these circumstances, econometric analyses of the economy as a whole are badly misleading, especially in the case of production functions and coefficients of income distribution. The analyses and policies - the ideas and leadership - in respect of the underdeveloped African periphery need to concentrate on the differential institutional conditions in this sector where transformation is needed, before the people involved will escape from their "vicious circle of poverty". The present relief programmes and safety nets of the government are providing the main source of survival for the people, but these actions do not constitute a platform for autonomous growth at the grass roots level on the basis of the initiative of the people themselves. And the situation in fact demands rapid growth.

Although government is encouraging expansion and enrichment of primary and technical education towards individual responsibility, to cultivate personality traits assumed in the neo-classical theory of market orientated societies, initiatives with more immediate effect are needed, in order for the periphery to escape from its economic stagnation into rapid growth. These are steps to reduce the serious obstacles to the emergence of active "specialisation and trade" among the thousands of households currently at loss of a way out. (It is, in a sense, reviving the idea of "inward industrialisation" for the periphery). Market failures that restrain growth include heavy transaction costs in the form of the absence of readily available market information and transport facilities, as well as other supporting public works. The very segmented market activities in the rural areas prevent economies of scale and other marketing advantages. The situation in the periphery calls for a proper appreciation of the infant industry argument, for adequate periods of support of individual enterprise in these areas. 
The initiatives needed for the upliftment of the periphery, to reduce the economic dualism and distributive inequality in the South African society, should not be seen as the responsibility of the government alone, especially not that of central government alone. The private sector in the core economy has proven its attitude towards the need for upliftment through the Business Trust of the National Business Initiative. But the situation seems to call for much decentralisation of responsibility to persons and institutions in the periphery itself, for the identification and execution of tasks.

In dedicating his work to his friend, Dr Charles Gore, Tawney adds the following poignant quotation from Bishop Berkeley:

"Whatever the world thinks, he who hath not much meditated on God, the human mind, and the summum bonum, may possibly make a thriving earthworm, but will most indubitably make a sorry patriot and a sorry statesman."

\section{Consulted literature}

Arndt, H W 1988. "Market Failure and underdevelopment", World Development, $15(2)$.

Barcley, W. 1971. Devotional reading for everyday. London: Hadder \& Stoughton.

Baumol, W J 1986. Superfairness: Applications and Theory. Cambridge: MIT Press.

Boulding, K E 1970. A primer on social dynamics: History as dialectics and development, New York: The Free Press.

Coetzee, S F 1991. "Development economics and policies to promote peace in South Africa", inaugural lecture, UNISA.

Davenport, T R U 1969. South Africa: A modern history. South Africa: Macmillan.

Ebenstein, W 1969. Great Political thinkers, Plato to the present. Illinois: Dryden Press.

Graaf, J de V 1971. Theoretical welfare economics. (Reprinted), Cambridge University Press.

Halliday, R 2001. Which economic system is just?, http://royhalliday.home.mindspring.com/c7.html.

Hayek, R A 1955. The political ideal of the Rule of Law.

Kohn, H 1945. The Idea of Nationalism. New York: Macmillan

Mandela, N 1995. Long walk to freedom. The autobiography of Nelson Mandela. London: Macdonald Purnell.

Meade, J E 1976. The just economy: Principles of political economy, Guildford: Billing \& Sons Limited.

Meer, F 1998. Higher than hope. The authorised biography of Nelson Mandela. London: Hamish Hamilton.

Prinsloo, D 1997. Stem uit die wildernis: 'n Biografie oor oud-president $P$ W Botha. Vaandel Uitgewers.

Robbins, L 1964. Politics and economics. London: Macmillan. 
Schumpeter, J 1947. Capitalism, socialism and democracy. London: George Allen and Unwim.

Sono, T 1999. From poverty to property: Five steps to deal transformation. FMF Books.

Tawney, R H 1937. Religion and the Rise of Capitalism, Middlesex: Penguin Books.

Tinbergen, J 1956. Economic Policy: Principles and Design, Amsterdam. 